\title{
FORMAÇÃO DOCENTE ONLINE EM EDUCAÇÃO FINANCEIRA: UMA PROPOSTA DE SABERES E PRÁTICAS
}

\section{ONLINE EDUCATION IN TEACHING FINANCIAL EDUCATION: A PROPOSAL OF KNOWLEDGE AND PRACTICE}

\author{
Rosangela Ramon ${ }^{1}$ \\ Alcione Cappelin ${ }^{2}$ \\ Regis Alessandro Fuzzo ${ }^{3}$ \\ Clodis Boscarioli ${ }^{4}$
}

\begin{abstract}
Resumo: O presente artigo traz uma proposta de um curso online de curta duração sobre Educação Financeira como formação continuada para professores, cujas atividades elaboradas privilegiam a utilização de diversas ferramentas que estimulam a aprendizagem e a elaboração de atividades para realização com seus alunos. O documento aborda também como o curso está estruturado, o modelo de design instrucional utilizado, as atividades a serem realizadas, bem como reflexões do porquê das escolhas realizadas. Para além disso, é apresentada uma reflexão sobre a importância de trabalhar a educação financeira nas escolas, na abordagem dada pela Base Nacional Comum Curricular e à luz da Estratégia Nacional de Educação Financeira sobre o tema.
\end{abstract}

Palavras-chave: Formação continuada online; Educação Financeira; Resolução de problemas.

Abstract: This paper presents a proposal for a Financial Education's online short course as a continuing education for teachers, whose elaborated activities favor the use of several tools that encourage learning, and development of activities to perform with his students. The document also discusses how the course is structured, the instructional design model used, the activities to be accomplished, as well the reflections about the choices made. In addition, a reflection about the importance of working financial education in schools, on the approach given by the National Curricular Common Base and considering the National Financial Education Strategy about the subject.

Keywords: Online Continuing Education; Financial Education; Problem Solving.

\footnotetext{
${ }^{1}$ Mestre em Modelagem Matemática pela Universidade Regional do Noroeste do Estado do Rio Grande do Sul (UNIJUI). Professora do Instituto Federal de Santa Catarina (IFSC), Xanxerê, Santa Catarina, Brasil. E-mail: rosangela.ramon@ifsc.edu.br

2 Mestre em Educação em Ciências e em Matemática pela Universidade Federal do Paraná (UFPR). Professora na Faculdade de Pato Branco (FADEP), Pato Branco, Paraná, Brasil. E-mail: alcionecappelin2912@gmail.com

${ }^{3}$ Especialista em Educação: Métodos e Técnicas de Ensino pela Universidade Tecnológica Federal do Paraná (UTFPR). Servidor na Universidade Tecnológica Federal do Paraná, Santa Helena, Paraná, Brasil. E-mail: regisfuzzo@gmail.com

${ }^{4}$ Doutor em Engenharia Elétrica pela Universidade de São Paulo (USP). Professor Associado da Universidade Estadual do Oeste do Paraná (Unioeste), Cascavel, Paraná, Brasil. E-mail: boscarioli@gmail.com
} 


\section{Introdução}

Atividades de formação continuada devem estar presentes na vida dos professores para sua constante atualização e qualificação profissional, dado que diversas temáticas surgem no decorrer dos anos e que estas, muitas vezes, não foram exploradas, ou não o foram em profundidade, durante o processo da formação inicial, como é o caso da Educação Financeira, tema de extrema relevância na atual conjectura, que emerge pela necessidade de explorar nas escolas conceitos e atividades que contribuam para melhorar o grau de conhecimento nessa área, atingindo os objetivos apresentados na Base Nacional Comum Curricular (BNCC), homologada em 2018, que enfatiza em seu texto que na educação básica deve-se desenvolver e explorar habilidades voltadas à Educação Financeira. Cabe destacar que, conforme a BNCC, a Educação Financeira não fica a cargo apenas dos componentes curriculares de Matemática, mas deve ser abordado de forma interdisciplinar, envolvendo as diversas áreas do conhecimento.

A formação continuada, em cursos de pequena duração, passa a ser então importante para o aprimoramento da prática pedagógica. Este artigo apresenta o processo de construção de um curso de formação continuada sobre Educação Financeira na modalidade da Educação a Distância $(\mathrm{EaD})$ para professores que atuam no Ensino Fundamental e Médio, com atividades apresentadas com o viés da teoria de resolução de problemas, buscando explorar a interdisciplinaridade, e que poderão ser facilmente adaptadas para as salas de aulas.

A opção pela formação online se deu com o intuito de romper as barreiras do espaço-tempo, visto que, os professores da Educação Básica, na sua maioria, possuem uma carga horária de aula significativa e possuem dificuldade de realizar o curso presencialmente. A carga horária do curso é de 60 horas e está projetado para explorar a Educação Financeira com base, principalmente, na resolução de problemas.

O curso online de formação continuada para professores de Matemática da Educação Básica, objeto deste texto, é intitulado "Educação Financeira, meu aluno precisa disso?" e surgiu a partir de uma atividade de ensino no Programa de PósGraduação em Educação em Ciências e Educação Matemática (PPGECEM) da Universidade Estadual do Oeste do Paraná (Unioeste), campus de Cascavel. O tema Educação Financeira foi escolhido por ser considerado relevante para a formação crítica dos estudantes, precisando ser melhor compreendido pelos professores. Outro ponto que 


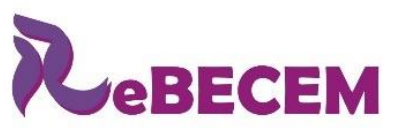

DOI: http://dx.doi.org/10.33238/ReBECEM.2019.v.3.n.2.22611

influenciou a escolha do tema foi a homologação da BNCC que enfatiza a abordagem da Educação Financeira na Educação Básica.

Após a sua criação, o curso, passou por um processo de avaliação, onde três professores de Matemática atuantes na Educação Básica (rede pública) e com conhecimentos no processo de criação de cursos na perspectiva das teorias de Design Instrucional fizeram uma análise crítica das atividades abordadas. Esses professores tiveram acesso ao curso na sua totalidade, e analisaram todo o material disponibilizado assim como, a metodologia e as ferramentas empregadas nas atividades propostas. Após essa análise, os avaliadores apresentaram seus relatórios, indicando aspectos positivos, negativos e sugestões, que serviram de base para a realização de ajustes e melhorias.

Este documento segue assim organizado: Apresentamos na segunda seção os aspectos teóricos que nortearam a proposta de formação ora apresentada. A terceira seção é destinada à apresentação da proposta de implementação do curso no Moodle (Modular Object-Oriented Dynamic Learning Environment), bem como as decisões de projeto. Na sequência, são apresentadas as conclusões e perspectivas do trabalho.

\section{Aspectos teóricos}

Buscando embasar o trabalho apresentaremos os pontos chaves que norteiam e justificam a construção do curso aqui proposto: Formação Continuada, Educação Financeira e Resolução de Problemas. Trata-se de uma abordagem de visão geral sobre esses temas. Há de se destacar que, embora independentes, esses temas se articulam e se complementam no curso proposto.

\subsection{Formação continuada}

Ainda que o professor seja peça fundamental nos processos de ensino e aprendizagem, é preciso que tenha em mente que não é mais o detentor do saber, mas que esteja disposto a mudar sua prática a fim de que os alunos consigam interagir e se posicionarem como coautores do processo de ensino, encaminhando os alunos diante das múltiplas possibilidades e formas de alcançar o conhecimento e de se relacionar com ele.

A formação continuada neste sentido é encarada como um meio de articular antigos e novos conhecimentos nas práticas dos professores, a luz da teoria, gerando de certa forma, mudanças e transformações, considerando os aspectos da formação em que se baseiam tais práticas, uma vez que estas são fundamentadas em construções individuais e coletivas que ocorrem durante o tempo e nas suas relações (WENGZYNSKI; TOZETTO, 2012, p. 4). 


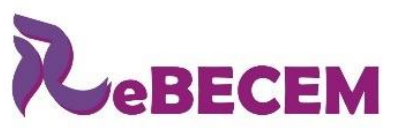

Revista Brasileira de Educação em

Ciências e Educação Matemática

DOI: http://dx.doi.org/10.33238/ReBECEM.2019.v.3.n.2.22611

Segundo Ghedin (2012, p. 165) "não há conhecimento pronto e acabado, do mesmo modo que não há vida absoluta. Tudo é processo contínuo de construção e de autoconstrução". A formação continuada, de forma geral, é entendida como um processo que permite dar continuidade no desenvolvimento profissional dos educadores, e assim, melhorar a prática pedagógica. Essa formação “[..] conquista espaço privilegiado por permitir a aproximação entre os processos de mudança que se deseja fomentar no contexto da escola e a reflexão intencional sobre as consequências destas mudanças" (WENGZYNSKI; TOZETTO, 2012, p. 3). Para esses autores, a formação continuada contribui para o desenvolvimento do conhecimento profissional do professor proporcionando reflexões sobre a própria prática docente.

Dessa forma, os educadores devem buscar novas formas do saber, novos métodos para desenvolver e produzir o conhecimento científico. O professor deve estar em constante processo de formação visto que, somente assim poderá contribuir para a formação de cidadãos críticos e ativos na sociedade. Para Fiorentini (2008)

Os saberes e os processos de ensinar e aprender, tradicionalmente desenvolvidos pela escola, se tornaram cada vez mais obsoletos e desinteressantes para os alunos. O professor passou, então, a ser continuamente desafiado a atualizar-se e tentar ensinar de um modo diferente daquele vivido em seu processo de escolarização e formação profissional (FIORENTINI, 2008, p. 45).

O avanço da internet e o uso cada vez mais frequente de tecnologias digitais permitiram mais facilidades de acesso ao conhecimento, possibilitando aos docentes realizarem formações na modalidade $\mathrm{EaD}$, de forma online. No Brasil, a $\mathrm{EaD}$ é considerada

[...] a modalidade educacional na qual a mediação didático-pedagógica nos processos de ensino e aprendizagem ocorra com a utilização de meios e tecnologias de informação e comunicação, com pessoal qualificado, com políticas de acesso, com acompanhamento e avaliação compatíveis, entre outros, e desenvolva atividades educativas por estudantes e profissionais da educação que estejam em lugares e tempos diversos (BRASIL, 2017).

Os cursos ofertados utilizam-se dos mais variados ambientes virtuais de ensino e aprendizagem, dentre eles o Moodle, adotado pela Unioeste como sua plataforma para cursos a distância e como ambiente de apoio ao ensino presencial, que apresenta uma diversidade de recursos, como chat, fórum, questionário, entre outros. O Moodle, possibilita realizar atividades interativas por meio de bate-papo, fóruns, questionários, dentre outros recursos, no qual também é possível que os cursistas tenham acesso às atividades realizadas pelos demais estudantes e interajam com elas, além de possibilitar 


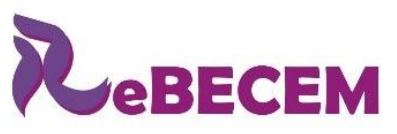

DOI: http://dx.doi.org/10.33238/ReBECEM.2019.v.3.n.2.22611

o monitoramento das atividades propostas, permitindo ao professor acompanhar o processo de aprendizagem dos cursistas.

A formação de professores mediada por ambientes virtuais possibilita "aproximar pessoas geograficamente distantes, possivelmente abrindo espaço à troca entre culturas diferentes" (BORBA; MALHEIROS; AMARAL, 2011, p. 25). Além disso, podemos citar como características específicas da educação a distância: flexibilidade, atemporalidade, extraterritoriedade, interatividade e facilidade de escalonamento. "Nesse sentido, a EaD torna-se uma solução extremamente viável, por sua possibilidade de formar sujeitos dispersos geograficamente, alcançando uma maior abrangência territorial, com menores gastos" (PEREIRA; LARANJO; FIDALGO, 2012, p. 4).

A BNCC menciona a formação inicial e continuada, e cita que para atender aos objetivos do documento, além da mudança nos currículos a formação inicial e continuadas dos educadores precisa ser repensada.

\begin{abstract}
A BNCC por si só não alterará o quadro de desigualdade ainda presente na Educação Básica do Brasil, mas é essencial para que a mudança tenha início porque, além dos currículos, influenciará a formação inicial e continuada dos educadores, a produção de materiais didáticos, as matrizes de avaliações e os exames nacionais que serão revistos à luz do texto homologado da Base. (BRASIL, 2018, p. 5)
\end{abstract}

Nesse sentido, o curso proposto busca dar subsídios para que professores da Educação Básica desenvolvam atividades que contribuam à melhoria do grau de Educação Financeira dos estudantes.

\title{
2.2 Educação Financeira
}

De acordo com o Banco Central do Brasil - BCB (2013, p. 7), órgão regulador e supervisor do Sistema Financeiro Nacional (SFN),

\begin{abstract}
a educação financeira é o meio de prover conhecimentos e informações sobre comportamentos básicos que contribuem para melhorar a qualidade de vida das pessoas e de suas comunidades. É, portanto, um instrumento para promover o desenvolvimento econômico. Afinal, a qualidade das decisões financeiras dos indivíduos influencia, no agregado, de toda a economia por estar intimamente ligada a problemas de endividamento e inadimplência das pessoas e a capacidade de investimento dos países.
\end{abstract}

Podemos encontrar definição semelhante sobre Educação Financeira, na Organização para a Cooperação e Desenvolvimento Econômico (OCDE, 2005), que caracteriza como o processo que permite o entendimento sobre produtos, conceitos e riscos financeiros, desenvolvem habilidades para fazerem escolhas mais conscientes e, 


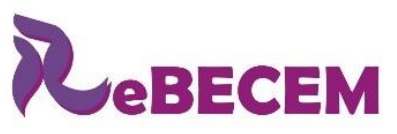

Revista Brasileira de Educação em

Ciências e Educação Matemática

DOI: http://dx.doi.org/10.33238/ReBECEM.2019.v.3.n.2.22611

portanto, aplicarem procedimentos para melhorar seu bem-estar (OCDE, 2005 apud Santos, 2009).

As definições supracitadas afirmam que a Educação Financeira permite a construção de conhecimentos que contribuem para escolhas mais conscientes por parte das pessoas. Na busca de promover ações de educação financeira no Brasil, em 2010, criou-se a Estratégia Nacional de Educação Financeira (ENEF), e dentre os objetivos elencados no documento estão o de promover a educação financeira, a educação previdenciária e contribuir para o fortalecimento da cidadania, a tomada de decisões conscientes.

No tocante às diretrizes de implementação, o Decreto Federal nº 7.397 de criação da ENEF, esclarece que

Art. 2o A ENEF será implementada em conformidade com as seguintes diretrizes:

I - atuação permanente e em âmbito nacional;

II - gratuidade das ações de educação financeira;

III - prevalência do interesse público;

IV - atuação por meio de informação, formação e orientação;

V - centralização da gestão e descentralização da execução das atividades;

VI - formação de parcerias com órgãos e entidades públicas e instituições privadas; e

VII - avaliação e revisão periódicas e permanentes (BRASIL, 2010).

Fica assim determinado que a ENEF será uma atividade a ser realizada em todo o território nacional com descentralização de atividades, de forma gratuita e permanente, buscando órgãos parceiros de entidades pública e privadas. Neste sentido, o Banco Central do Brasil (BCB 2013) elaborou um Caderno de Educação Financeira, pautado na ENEF, que apresenta seis conhecimentos básicos providos pela Educação Financeira que contribuem para a melhora na qualidade de vida do cidadão.

Os tópicos apresentados na Figura 1 visam reflexões que enfatizam a compreensão de hábitos de consumo, potenciais causas e consequências de endividamentos, importância do planejamento financeiro para a aposentadoria, riscos financeiros e quais as medidas de prevenção e proteção adequadas para cada situação, como transformar sonhos em realidade, atitudes que podem ser adotadas para evitar o consumo impulsivo, entre outros. 
Figura 1: Os seis conhecimentos de Educação Financeira

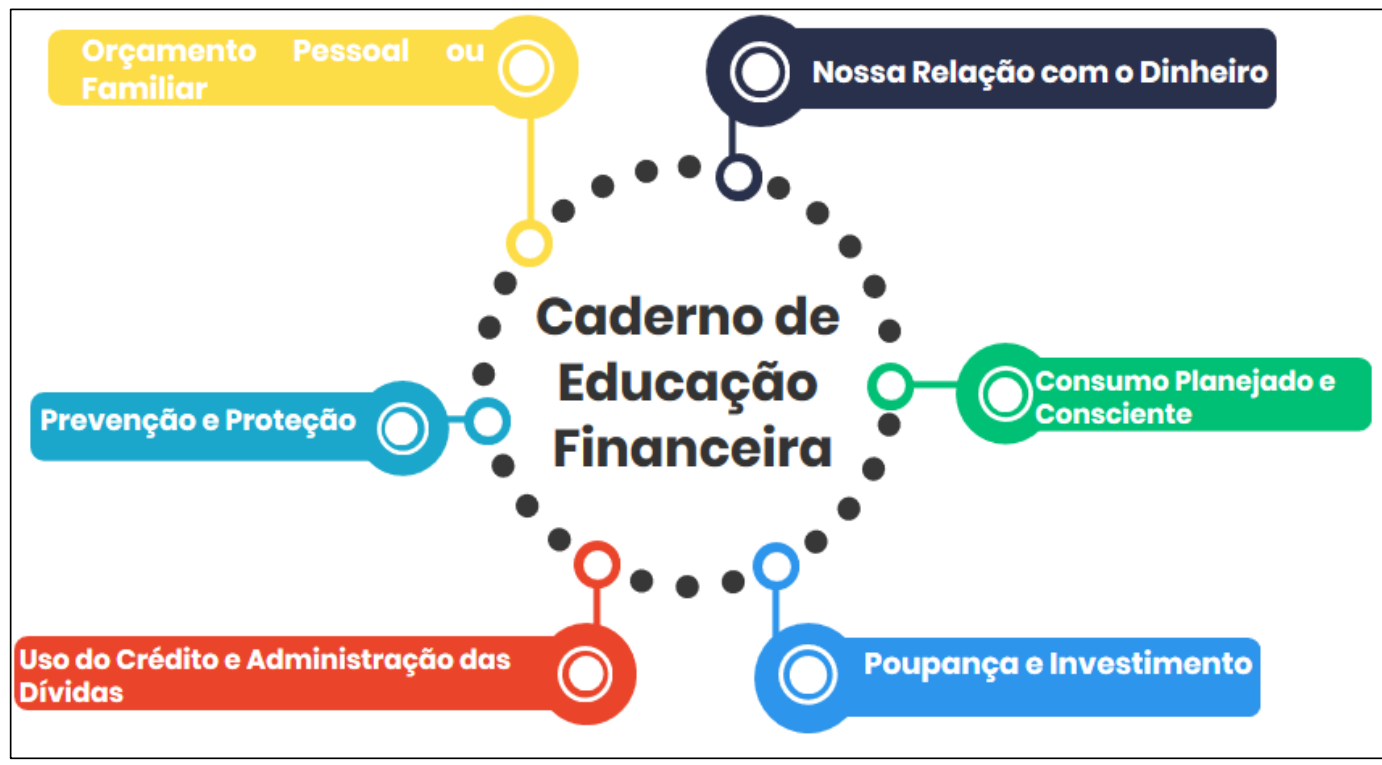

Fonte: Elaborada pelos autores com base no Caderno de Educação Financeira

Reforçando a importância da Educação Financeira, Santos (2009) afirma que a ausência de conhecimento básico, como proposto pelo BCB, expõe os cidadãos a atitudes de pessoas mal-intencionadas, ficando vulneráveis e podendo ser enganadas. Relata ainda que a falta de conhecimento resulta em atitudes financeiras irresponsáveis, aumentando os níveis de inadimplência, pelo fato de não estar preparado para enfrentar dificuldades financeiras ou compromissos financeiros acima da sua capacidade.

No Brasil, há uma conjuntura preocupante em relação à Educação Financeira, necessitando da introdução deste tema em todas as esferas, devido à grande desigualdade de distribuição de renda, na qual o Estado possui grande parte da representatividade dos recursos, demandando uma excelência na gestão de recursos. Além de vigiar as ações e iniciativas do setor privado, o papel do setor público é de extrema relevância para divulgação, fortalecimento e consolidação da Educação Financeira, sendo a participação do setor educacional, ou seja, as escolas e universidades, de grande importância para o seu êxito (SAVOIA; SAITO; SANTANA, 2007).

Segundo Pessoa, Muniz, Kistemann (2018), para aperfeiçoar as ações no que se refere à Educação Financeira como meio de prover conhecimentos e informações (BCB, 2013) ou como processo que permite o entendimento sobre produtos, conceitos, riscos e desenvolver habilidades (OCDE, 2005 apud Santos, 2009), os autores afirmam que os educadores são os mais capacitados para tais ações, em um ambiente escolar.

Ainda nesta mesma linha de raciocínio, Pessoa, Muniz e Kistemann (2018), sustentam que a ação desses educadores deve ser definida pela mediação dos conteúdos 


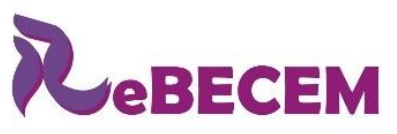

DOI: http://dx.doi.org/10.33238/ReBECEM.2019.v.3.n.2.22611

e das informações relevantes para a oferta de Literacia Financeira ${ }^{5}$, fundamentada em pressupostos de cidadania e ética.

Sobre a competência da tomada de decisão proporcionada por tarefas problematizadas na sala de aula, estes mesmos autores, apontam que se devem utilizar materiais e livros didáticos que superam o exclusivo uso de algoritmos e fórmulas rotineiras. Sugerem que este ambiente favorável de aprendizagem ocorra por meio da mediação docente, promovendo um pensar crítico que considere aspectos matemáticos e não matemáticos (PESSOA; MUNIZ; KISTEMANN; 2018).

\subsubsection{A Educação Financeira na BNCC}

Em 2018, foi publicado pelo Ministério da Educação, a Base Nacional Comum Curricular (BNCC), que é um documento de caráter normativo que define o conjunto orgânico e progressivo de aprendizagens essenciais que todos os alunos devem progredir ao longo das etapas e modalidades da Educação Básica (BRASIL, 2018).

A BNCC ainda ressalta que essas aprendizagens essenciais devem convergir para assegurar aos estudantes o desenvolvimento de competências gerais, definida como "a mobilização de conhecimentos (conceitos e procedimentos), habilidades (práticas, cognitivas e socioemocionais), atitudes e valores para resolver demandas complexas da vida cotidiana [...]." (BRASIL, 2018, p. 8).

Além disso, o documento afirma que a BNCC e os currículos dos sistemas e das redes escolares, além das propostas pedagógicas, possuem atribuições complementares para sustentar as aprendizagens essenciais definidas para cada etapa da Educação Básica. Neste sentido, a BNCC revela que compete aos sistemas e redes de ensino, agregar aos currículos e às propostas pedagógicas a abordagem dos temas contemporâneos que interferem a vida humana em extensão local, regional e global, preferencialmente de forma transversal e integradora.

Entre esses temas, destacam-se “[...] educação para o consumo, educação financeira e fiscal [...]" (BRASIL, 2018, p. 20), e dentro da área de matemática, é proposto cinco unidades temáticas, sendo elas: Números, Álgebra, Geometria, Grandezas e medidas e Probabilidade e estatística. Na unidade temática Números, uma perspectiva

\footnotetext{
5 Termo utilizado por Pessoa, Muniz, Kistemann (2018) como uma aptidão adquirida e desenvolvida por um sujeito característico da sociedade de consumo, em contextos socioeconômicos, que toma decisões a partir do seu conhecimento sobre finanças.
} 
DOI: http://dx.doi.org/10.33238/ReBECEM.2019.v.3.n.2.22611

considerada é o estudo de conceitos básicos de economia e finanças, visando à educação financeira dos alunos (BRASIL, 2018).

Dessa forma, a BNCC sugere para serem discutidos assuntos como taxas de juros, inflação, aplicações financeiras (rentabilidade e liquidez de um investimento) e impostos. Ainda, afirma que essa unidade temática "favorece um estudo interdisciplinar envolvendo as dimensões culturais, sociais, políticas e psicológicas, além da econômica, sobre as questões do consumo, trabalho e dinheiro" (BRASIL, 2018, p. 269).

Seguindo a recomendação de trabalhar os conteúdos de forma transversal e integradora, a BNCC relata que a temática da Educação Financeira oportuniza desenvolver projetos e se relacionar com outras áreas do conhecimento, tal que esses assuntos, além de viabilizar o desenvolvimento de competências pessoais e sociais dos alunos, permitem "se constituir em excelentes contextos para as aplicações dos conceitos da Matemática Financeira e proporcionar contextos para ampliar e aprofundar esses conceitos" (BRASIL, 2018, p. 269).

Pessoa, Muniz e Kistemann (2018) apresentam uma reflexão sobre a distinção da Educação Financeira voltada aos interesses mercadológicos e a Educação Financeira Escolar, objeto de interesse da Educação Matemática. Para estes pesquisadores, quando este tema é discutido nas escolas permite um trabalho reflexivo sobre consumo consciente, tomada de decisão, anseios versus necessidade, influência midiática, afirmando que a Matemática não pode ser o único fator para uma tomada de decisão sustentável.

Seguindo este raciocínio sobre a importância de trabalhar a Educação Financeira no ambiente escolar, e apropriando-se da Educação Matemática para embasar os direcionamentos das práticas pedagógicas, encontramos em Cunha e Laudares (2017) uma alternativa, pautada na resolução de problemas, para inserir o contexto do mundo globalizado que exige tomadas de decisão urgentes sobre diversas situações em sala de aula. Para Cunha e Laudares, (2017) a tendência da resolução de problemas permite inserir este contexto e aprendizagem, pois exige uma construção organizacional e argumentativa para gerir dados numa estrutura, que sempre está evidente numa problematização.

Na concepção desses últimos autores a proposta de contextualizar a Matemática Financeira no Ensino Médio, fundamentada pela Educação Financeira junto à resolução de problemas, alcança possibilidades para que o estudante seja inserido no mundo financeiro e na verdadeira intencionalidade da escola, que é preparar e formar o cidadão. 


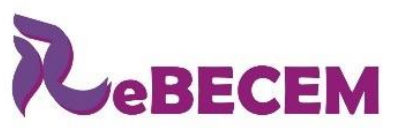

DOI: http://dx.doi.org/10.33238/ReBECEM.2019.v.3.n.2.22611

Ainda, afirmam que essa formação somente ocorre pelo uso do conhecimento adquirido, no aspecto de habilidades e competência, para prover a transformação da realidade do próprio indivíduo e, como resultado, do ambiente o qual está inserido.

\title{
2.3 Resolução de problemas
}

Criar possibilidades para que os educandos desenvolvam habilidades como a criatividade, a interpretação, o raciocínio lógico, a autonomia intelectual e a análise crítica deve ser o ponto de partida para o ensino da matemática, e essas habilidades podem ser fortalecidas quando se utiliza da resolução de problemas como estratégia de ensino. Para Hatfield

\begin{abstract}
Aprender a resolver problemas matemáticos deve ser o maior objetivo da instrução matemática. Certamente outros objetivos da Matemática devem ser procurados, mesmo para atingir o objetivo da competência em resolução de problemas. Desenvolver conceitos matemáticos, princípios e algoritmos através de um conhecimento significativo e habilidoso é importante. Mas o significado principal de aprender tais conteúdos matemáticos é ser capaz de usá-los na construção das soluções das situações-problema (HATFIELD, 1980 apud DANTE, 1998, p. 8)
\end{abstract}

Dante (2005) destaca que uma situação só pode ser considerada como problema se não dispomos de procedimentos automáticos que permitam solucioná-la, e que sem a exigência de um processo de reflexão ou a tomada de decisões sobre a sequência de passos a serem seguidos, não temos um problema. $\mathrm{O}$ autor enfatiza que muitas vezes se confunde problema com exercícios de fixação, e que a resolução de problemas deve fazer o aluno pensar, desenvolver o raciocínio lógico, ensinar o aluno a enfrentar situações novas e levar o aluno a conhecer as primeiras aplicações da Matemática.

Resolver um problema vai muito além de resolver um exercício matemático. Um problema desafiante pode servir de base para o surgimento de outros problemas.

\footnotetext{
O fato de o aluno ser estimulado a questionar sua própria resposta, a questionar o problema, a transformar um dado problema numa fonte de novos problemas, a formular problemas a partir de determinadas informações, a analisar problemas abertos que admitem diferentes respostas em função de certas condições evidencia uma concepção de ensino e aprendizagem não pela mera reprodução de conhecimentos, mas pela via da ação refletida que constrói conhecimentos (BRASIL, 1998, p. 42).
}

Quando a resolução de problemas é utilizada para o ensino da Matemática, incentiva-se o aluno a aprender a aprender, a construir estratégias, a compreender conceitos, a desenvolver o raciocínio lógico e a questionar o mundo que o cerca de forma crítica, ou seja, a exercitar sua criticidade e sua criatividade. Esses elementos auxiliam para melhorar o grau de Educação Financeira nos estudantes. 


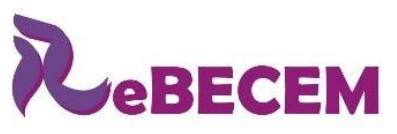

DOI: http://dx.doi.org/10.33238/ReBECEM.2019.v.3.n.2.22611

Assim, a resolução de problemas como estratégia de ensino vai ao encontro aos objetivos elencados ao se trabalhar com a educação financeira nas escolas. Dessa forma, o curso não se destina apenas para professores de Matemática, e poderá ser de interesse de professores das mais diversas áreas do conhecimento.

\section{A proposta de formação continuada}

Visando atender a BNCC (2018) e contribuir com os objetivos elencados na ENEF foi projetado um curso de formação continuada, de curta duração, na modalidade EaD que possibilite fortalecer a formação docente no que diz respeito a práticas educacionais na área da educação financeira.

As atividades propostas foram pensadas para professores que atuam na Educação Básica, em especial no Ensino Fundamental e Médio. Cabe destacar que, embora tenha uma ênfase na exploração da Matemática, o curso é aberto às diversas áreas do conhecimento, destinando, inclusive, um módulo com reflexões gerais sobre o tema.

A proposta do curso, de maneira geral, enfatiza a reflexão e o entendimento de conceitos presentes na Educação Financeira e apresenta ferramentas de apoio à aprendizagem, que podem ser utilizadas em aulas presenciais. Além de reflexões teóricas sobre o Educação Financeira o curso enfatiza atividades motivadoras para que o participante possa replicar/recriar em sua sala de aula, fazendo pequenas adequações caso julgar necessário. O curso, com certificação de 60 horas, prevê um prazo de quatro meses para que os cursistas o concluam.

As atividades propostas vislumbram enriquecer o cursista de conceitos e ideias de como explorar a Educação Financeira em sua prática pedagógica e, ao mesmo tempo, propiciar uma reflexão pessoal sobre o seu grau de Educação Financeira. Quando nos referimos à reflexão pessoal, esperamos com isso diminuir seu déficit de conhecimento nessa área e instigá-los a busca de novos conhecimentos sobre o tema.

Assim, suas atividades pessoais podem ser ponto de discussões na prática pedagógica. Outro ponto a destacar, são as experiências já vivenciadas pelos educadores em seu cotidiano escolar, apresentadas durante o curso por meio de relatos e exposição de atividades, e com esses compartilhamentos de experiências buscamos enriquecer o curso e motivar os demais professores na abordagem do tema ora proposto. 


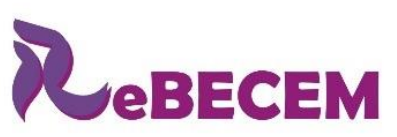

Revista Brasileira de Educação em

Ciências e Educação Matemática

DOI: http://dx.doi.org/10.33238/ReBECEM.2019.v.3.n.2.22611

Com base nessas finalidades optou-se por criar um curso no modelo ADDIE (Analysis, Design, Development, Implementation e Evaluation) e com Design Instrucional Aberto.

A Figura 2 apresenta as fases e as ações de design instrucional do curso desenvolvido seguindo o modelo ADDIE apresentado em Filatro (2008), que é dividido em duas fases: concepção e execução. Na primeira é realizada a análise, o design e o desenvolvimento do DI, e a segunda fase é destinada à implementação e à avaliação. Cabe destacar que, segundo Filatro (2008), o processo de avaliação deve passar por todas as fases do modelo, com intuito de sanar possíveis falhas.

Figura 2: Fases do Design Instrucional

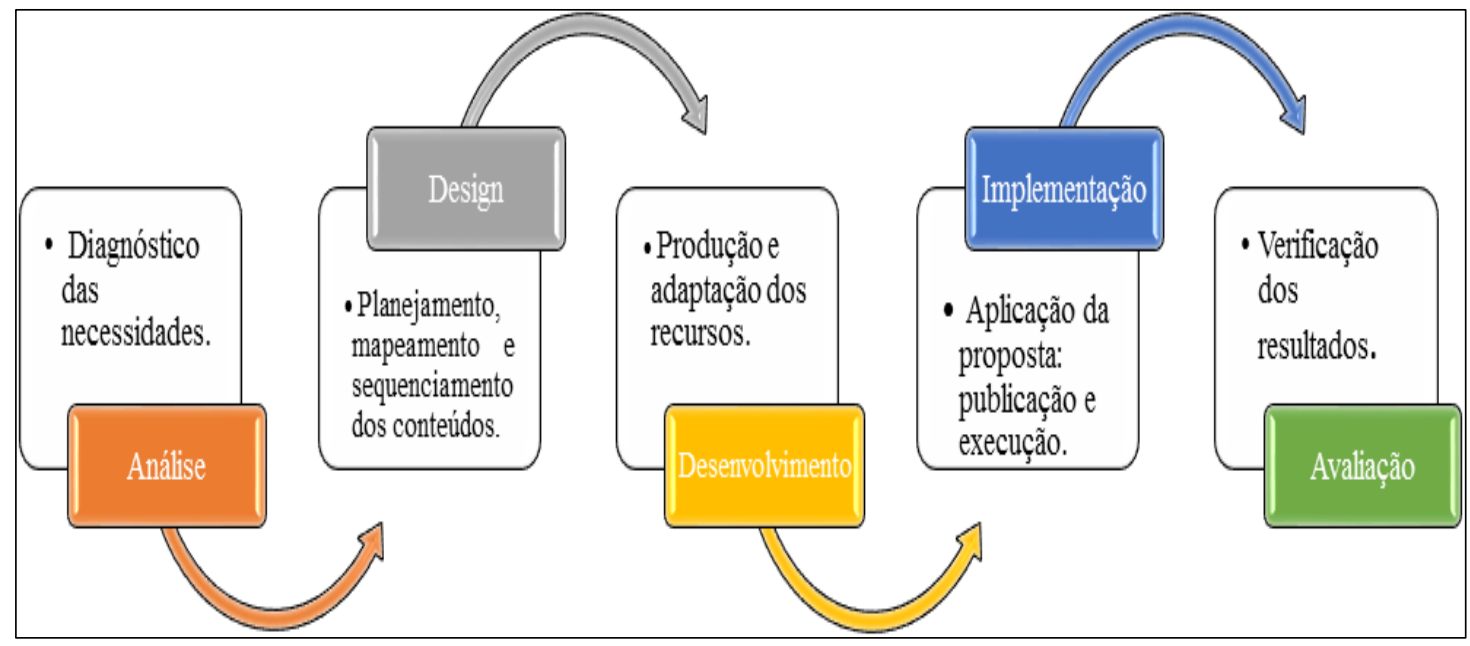

Fonte: Elaborada pelos autores segundo Filatro (2008)

O curso "Educação Financeira: Meu aluno precisa disso?” segue na perspectiva do Design Instrucional Aberto, que segundo Filatro (2008) privilegia a interação entre proponentes do curso e participantes. Essa interação é indispensável para a formação de professores, e possibilita proporcionar atividades que valorizam as experiências profissionais dos educadores e assim proporcionar um círculo de debates sobre o tema. Nesse modelo é possível fazer pequenas reestruturações durante o processo de execução, por exemplo, pode-se alimentar com mais materiais, caso seja necessário.

Essa escolha vem ao encontro do que Borba, Malheiros e Amaral (2011) afirmam sobre a EaD e a Matemática. "Quando o foco é a aprendizagem matemática, a interação é uma condição necessária no seu processo. Trocar ideias, compartilhar as soluções encontradas para um problema proposto, expor o raciocínio, são ações que constituem o “fazer matemática” (BORBA; MALHEIROS; AMARAL, 2011, p. 29). 


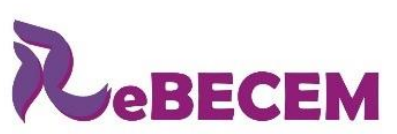

DOI: http://dx.doi.org/10.33238/ReBECEM.2019.v.3.n.2.22611

\subsection{O desenho pedagógico do curso}

O curso foi dividido em cinco módulos, de forma sequencial e articulada. As atividades avaliativas são apresentadas no decorrer do módulo e isso permite a realização de feedbacks parciais, proporcionando a intervenção do proponente do curso durante todo o processo de realização.

A Figura 3 apresenta um panorama geral das atividades a serem realizadas em cada um dos módulos, e a carga horária para tal.

Figura 3: A estruturação do curso

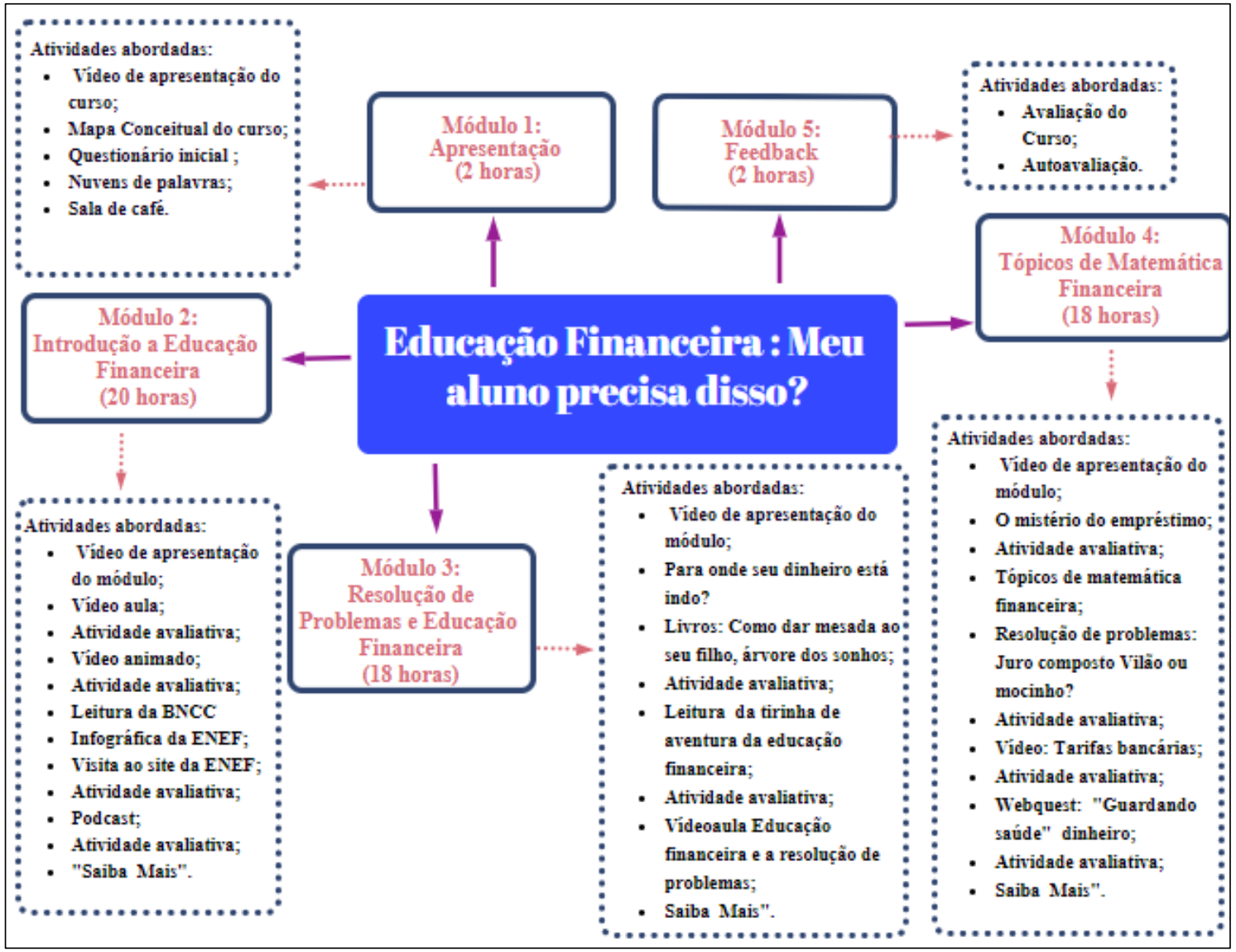

Fonte: Elaborada pelos autores

A Figura 4 traz o infográfico apresentado aos estudantes no início do curso no Moodle, que permite conhecer o objetivo geral de cada módulo. Assim, ao iniciar o processo de formação é possível ter clareza do que se almeja em cada uma das etapas. Um elemento de destaque presente em cada módulo é o item "Saiba Mais", focando em materiais que proporcionam ampliar os conhecimentos sobre o tema do curso, por meio de atividades reflexivas para o educador que atua na Educação Básica, além de atividades práticas que podem ser exploradas com seus alunos. 


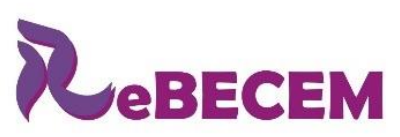

ISSN 2594-9179

DOI: http://dx.doi.org/10.33238/ReBECEM.2019.v.3.n.2.22611

Figura 4: Infográfico de apresentação dos objetivos do curso

\section{Educạ̧ão Financeira: Meu aluno precisa disso?}

\section{Conhę̧a as subdivisões do curso e o objetivo geral de cada módulo}

Módulo 2: Introdução à

Educaçäo Financeira

Objetivo: Conhecer documentos que norteiam e embasam 0 ensino da Educação Financeira nas escolas.

\section{Módulo 4: Tópicos de}

Matemática Financeira

Objetivo: Apresentar tópicos básicos da Matemática Financeira e disponibilizar/refletir sobre atividades para serem trabalhadas em sala de aula.

\section{Módulo 1 : Apresentaçäo}

Objetivo: Conhecer a dinâmica do curso e os participantes.

Módulo 3: Resolução de Problemas e Educação Financeira

Objetivo: Destacar a importância do uso de planilhas financeiras envolvendo atividades com foco na resolução de problema.

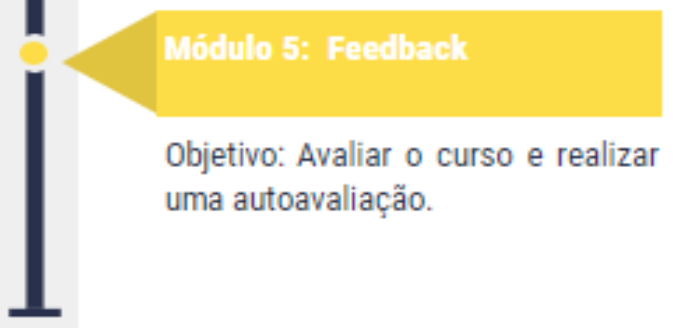

Fonte: Elaborada pelos autores

O Quadro 1 apresenta o curso em detalhes, a partir das unidades e objetos instrucionais/ferramentas de ensino e aprendizagens definidas para se trabalhar com cada conteúdo, detalhando também a forma de avaliação idealizada. Cabe aqui um destaque na pluralidade de formato dos materiais (podcast, vídeos, planilhas, charge, infográfico etc.), escolhidos para acomodar os diferentes estilos de aprendizagem e, também, para dinamizar a interação, propiciando que os professores cursistas tenham contato com diferentes tipos de mídias. 
DOI: http://dx.doi.org/10.33238/ReBECEM.2019.v.3.n.2.22611

Quadro 1: Objetos Instrucionais e Atividades Avaliativas

\begin{tabular}{|c|c|c|c|}
\hline Módulos & Unidades & Ferramentas & Avaliação \\
\hline \multirow{3}{*}{ Apresentação } & Apresentação do curso & $\begin{array}{l}\text { Vídeo animado; Texto em } \\
\text {.PDF, Mapa conceitual. }\end{array}$ & Sem atividade avaliativa. \\
\hline & $\begin{array}{l}\text { Conhecendo } \\
\text { cursistas }\end{array}$ & $\begin{array}{l}\text { Questionário inicial com } \\
\text { questões de múltipla escolha. } \\
\text { Fórum "Sala de café": texto } \\
\text { de apresentação. }\end{array}$ & Sem atividade avaliativa. \\
\hline & $\begin{array}{l}\text { Concepção de } \\
\text { Educação Financeira }\end{array}$ & $\begin{array}{l}\text { Nuvem de palavras com uso } \\
\text { do Poll Everywhere. }\end{array}$ & Sem atividade avaliativa. \\
\hline \multirow{5}{*}{$\begin{array}{l}\text { Introdução a } \\
\text { Educação } \\
\text { Financeira }\end{array}$} & $\begin{array}{l}\text { Apresentação do } \\
\text { Módulo }\end{array}$ & Vídeo animado. & Sem atividade avaliativa. \\
\hline & $\begin{array}{l}\text { Experiências com } \\
\text { Educação Financeira }\end{array}$ & $\begin{array}{l}\text { Videoaula; } \\
\text { Vídeo animado. }\end{array}$ & $\begin{array}{l}\text { Texto relatando experiências em } \\
\text { sala de aula com o tema; } \\
\text { Texto apresentando formas de } \\
\text { controle financeiro. }\end{array}$ \\
\hline & $\begin{array}{l}\text { Documentos } \\
\text { norteadores }\end{array}$ & $\begin{array}{l}\text { Texto sobre a BNCC; Link de } \\
\text { acesso à Estratégia Nacional } \\
\text { de Educação Financeira; } \\
\text { Infográfico. }\end{array}$ & $\begin{array}{l}\text { Questionário de múltipla } \\
\text { escolha. }\end{array}$ \\
\hline & $\begin{array}{l}\text { Reflexão sobre grau de } \\
\text { Educação Financeira } \\
\text { do brasileiro. }\end{array}$ & Podcast. & Participação em fórum. \\
\hline & Saiba Mais & $\begin{array}{l}\text { Vídeos com entrevistas; } \\
\text { artigos; livros; textos em PDF } \\
\text { com sugestões de atividades a } \\
\text { serem realizadas com } \\
\text { estudantes da Educação } \\
\text { Básica. }\end{array}$ & Sem atividade avaliativa. \\
\hline \multirow{6}{*}{$\begin{array}{l}\text { Resolução de } \\
\text { Problemas e } \\
\text { Educação } \\
\text { Financeira }\end{array}$} & $\begin{array}{l}\text { Apresentação do } \\
\text { Módulo. }\end{array}$ & Vídeo animado. & Sem atividade avaliativa. \\
\hline & $\begin{array}{l}\text { Para onde está indo seu } \\
\text { dinheiro? }\end{array}$ & $\begin{array}{l}\text { Link de acesso para livros; } \\
\text { texto em .PDF; uso de } \\
\text { planilhas. }\end{array}$ & $\begin{array}{l}\text { Realizar atividade de fluxo de } \\
\text { caixa usando metodologia de } \\
\text { resolução de problemas. }\end{array}$ \\
\hline & $\begin{array}{l}\text { Calvin e Haroldo em } \\
\text { "Uma aventura na } \\
\text { Educação Financeira" }\end{array}$ & Charge. & $\begin{array}{l}\text { Completar a Charge e publicar } \\
\text { no fórum. }\end{array}$ \\
\hline & $\begin{array}{l}\text { Situações matemáticas } \\
\text { do dia a dia para } \\
\text { explorar a } \\
\text { Financeira. }\end{array}$ & Videoaula. & $\begin{array}{l}\text { Envio de arquivo único no } \\
\text { formato .PDF de uma situação } \\
\text { do seu dia a dia que envolva } \\
\text { conhecimento de Educação } \\
\text { Financeira a ser explorada na } \\
\text { Educação Básica; } \\
\text { Comentar o trabalho de dois } \\
\text { colegas. }\end{array}$ \\
\hline & Saiba Mais & $\begin{array}{l}\text { Texto em .PDF; indicação de } \\
\text { leitura de livros e jogos de } \\
\text { tabuleiro e online. }\end{array}$ & Sem atividade avaliativa. \\
\hline & $\begin{array}{l}\text { Apresentação } \\
\text { Módulo. }\end{array}$ & Vídeo animado. & Sem atividade avaliativa. \\
\hline
\end{tabular}




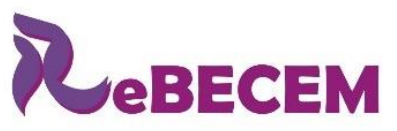

Revista Brasileira de Educação em

Ciências e Educação Matemática

ISSN 2594-9179

DOI: http://dx.doi.org/10.33238/ReBECEM.2019.v.3.n.2.22611

\begin{tabular}{|c|c|c|c|}
\hline \multirow{3}{*}{$\begin{array}{l}\text { Tópicos de } \\
\text { Matemática } \\
\text { Financeira }\end{array}$} & $\begin{array}{l}\text { O mistério do } \\
\text { empréstimo }\end{array}$ & Texto. & $\begin{array}{l}\text { Resolver o mistério do } \\
\text { empréstimo e postar no fórum. }\end{array}$ \\
\hline & Matemática Financeira & $\begin{array}{l}\text { Livro; texto em PDF; vídeo; } \\
\text { gráficos. }\end{array}$ & $\begin{array}{l}\text { Questionário; Participação no } \\
\text { fórum; envio de arquivo em } \\
\text {.PDF comparando juros simples } \\
\text { e compostos; }\end{array}$ \\
\hline & $\begin{array}{l}\text { Guardando saúde e } \\
\text { dinheiro }\end{array}$ & Webquest. & $\begin{array}{l}\text { Postar as planilhas com as } \\
\text { atividades propostas; }\end{array}$ \\
\hline Feedback & Avaliação do curso & $\begin{array}{l}\text { Vídeo de apresentação do } \\
\text { Módulo. }\end{array}$ & Questionário. \\
\hline
\end{tabular}

Fonte: Elaborado pelos autores

\subsubsection{Módulo 1 - Apresentação}

É destinado a apresentação dos participantes e do curso. É um módulo sucinto, mas nele é possível conhecer como o curso acontecerá. Ele é iniciado com um vídeo animado que motiva os estudantes a participarem do curso, conforme apresentado na Figura 5. Cabe salientar que todos os módulos possuem um vídeo semelhante, para sua introdução.

Figura 5: Imagens capturadas do vídeo introdutório do Módulo 1

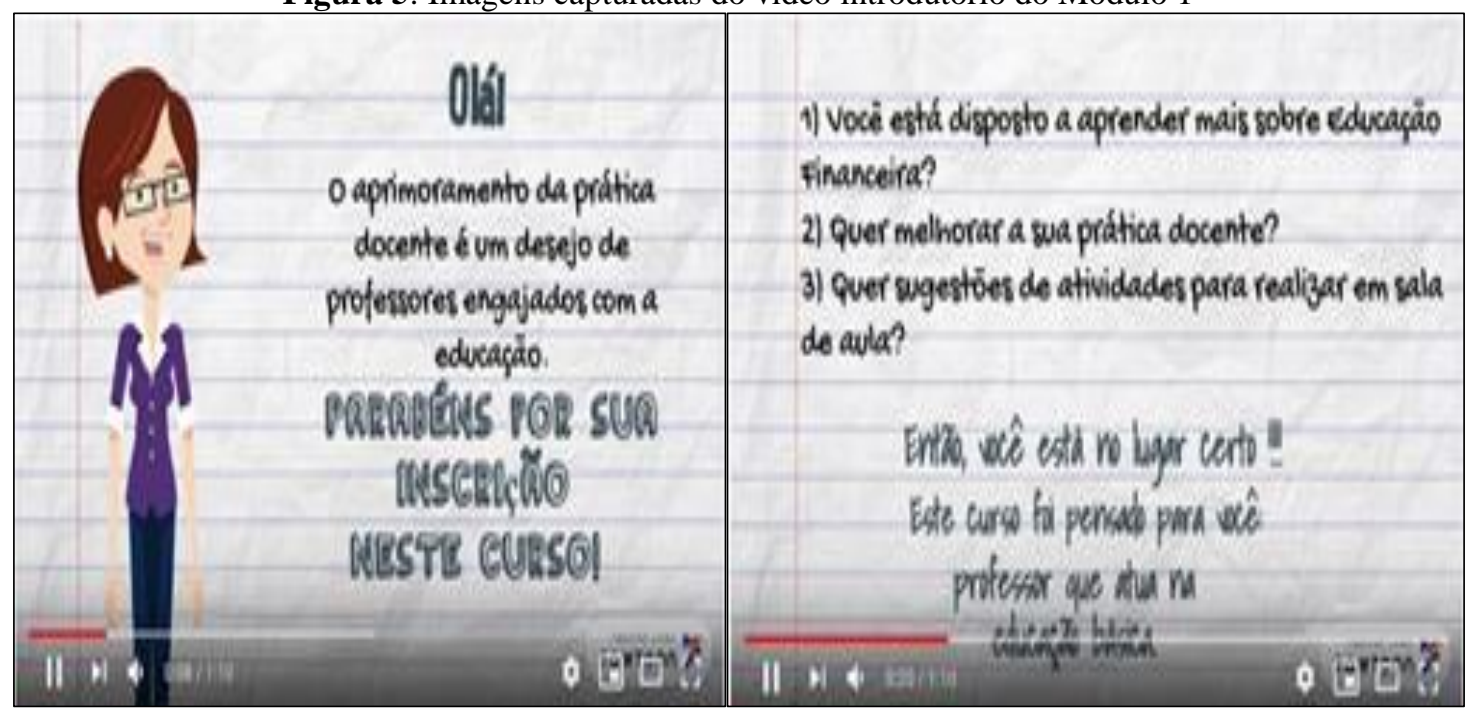

Fonte: Elaborada pelos autores

Esse módulo contempla uma atividade designada nuvem de palavras com objetivo de analisar a concepção dos cursistas sobre Educação Financeira. Na atividade o aluno descreve o ponto chave do tema em questão com apenas uma palavra. Essa atividade é disponibilizada a partir de um Link e $Q R$ Code um acesso a plataforma online Poll Everywhere. Como resposta da atividade forma-se um embaralhado de palavras, onde as 


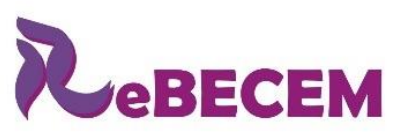

Revista Brasileira de Educação em

Ciências e Educação Matemática

DOI: http://dx.doi.org/10.33238/ReBECEM.2019.v.3.n.2.22611

palavras mais citadas ganham destaque na nuvem. A Figura 6 ilustra um possível resultado dessa atividade, onde é perceptível que para os cursistas a palavra planejamento está evidenciada.

Figura 6: Nuvem de palavras resultante de atividade

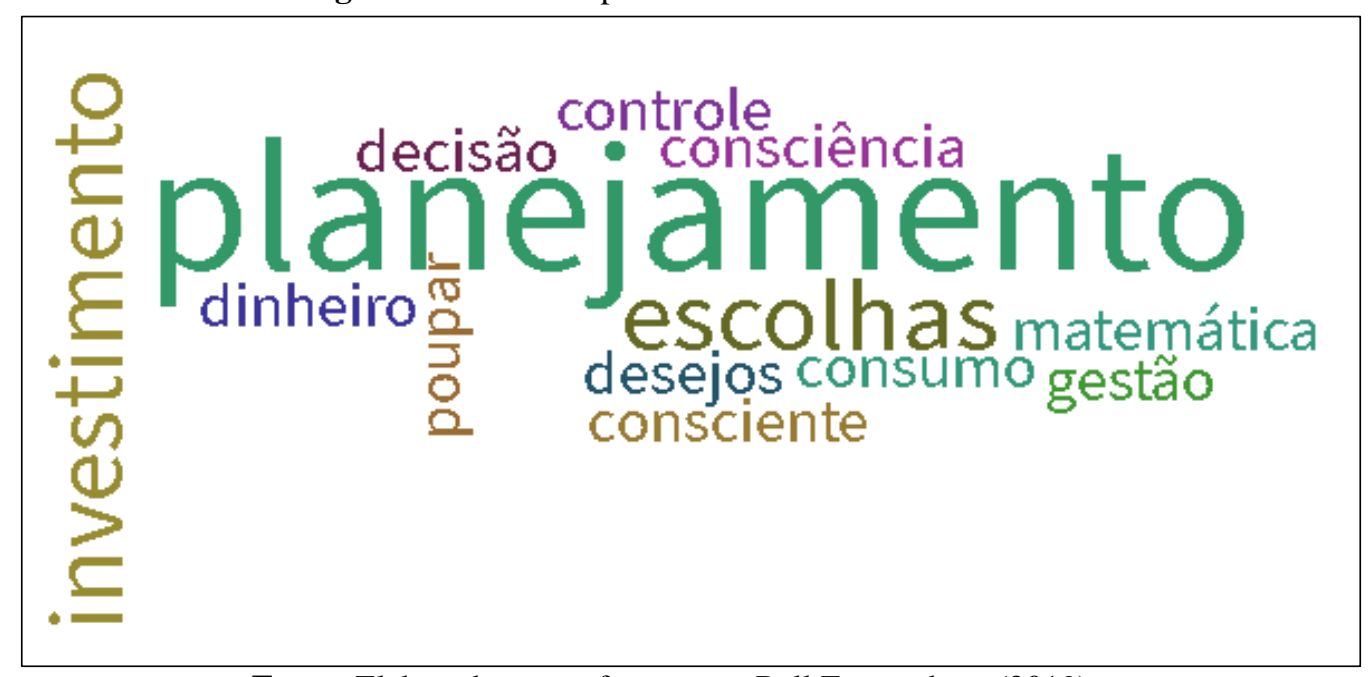

Fonte: Elaborada com a ferramenta Poll Everywhere (2019)

\subsubsection{Módulo 2 - Introdução à Educação Financeira}

O Módulo 2 foi projetado para abordar o conceito de educação financeira, bem como conhecer algumas estratégias em nível nacional que enfocam o tema.

Savoia, Saito e Santana, (2007) destacam alguns procedimentos para melhorar a carência de conhecimentos sobre Educação Financeira e, por consequência, a qualidade de vida dos cidadãos, como exemplo: inserir nos programas de todos os níveis de ensino, o tema da Educação Financeira; desenvolver os conceitos de finanças por meio das escolas, universidades, mídia e outros órgãos setoriais.

No decorrer do módulo são enfatizados diferentes elementos que ajudam na aprendizagem, como textos, videoaula, vídeos animados, infográficos, fóruns, questionários, entrevistas, podcast e livros. A utilização de diversos recursos se dá com o intuito de valorizar diversas formas de aprendizagem e para que o curso não se torne repetitivo e cansativo.

Logo após a apresentação do módulo está disponibilizada uma videoaula, que traz apontamentos e reflexões sobre a importância da inserção da educação financeira nas escolas. Esta é uma atividade introdutória sobre o tema, que motiva a busca de novos conhecimentos, e apresenta em dados a situação do povo brasileiro no que diz respeito a endividamentos. 


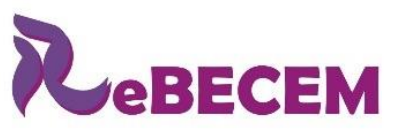

Revista Brasileira de Educação em

Ciências e Educação Matemática

DOI: http://dx.doi.org/10.33238/ReBECEM.2019.v.3.n.2.22611

A fim de proporcionar a interação sugere-se uma atividade em que os participantes do curso deverão relatar, via fórum, atividades realizadas por eles sobre educação financeira. Esse é um momento rico, pois proporciona, segundo Filatro (2008), discussões a partir dos textos postados pelos estudantes. Na visão dessa autora, os textos produzidos pelos estudantes são conteúdos que enriquecem o curso e consequentemente proporciona a construção do conhecimento pelos participantes.

Outro ponto de destaque desta atividade é a socialização de experiências bemsucedidas e a valorização dos conhecimentos prévios. Nesse tópico é sugerido pensar em atividades de forma interdisciplinar com o tema Educação Financeira. Cada participante deverá conhecer as atividades registradas por seus colegas e comentar pelo menos duas das experiências relatadas. Cabe ao proponente do curso, conduzir de forma eficiente essa atividade explorando ao máximo a abordagem dada pelos estudantes em seu texto. Buscando proporcionar mais reflexões sobre o tema, no curso, é sugerido que o cursista assista ao vídeo (Figura 7) que apresenta as ideias principais do livro Pai Rico, Pai Pobre de Kiyosaki (2017), e, posteriormente, redigir um texto fazendo apontamentos sobre controle financeiro e planejamento.

Figura 7: Cenas do vídeo Pai Rico, Pai Pobre

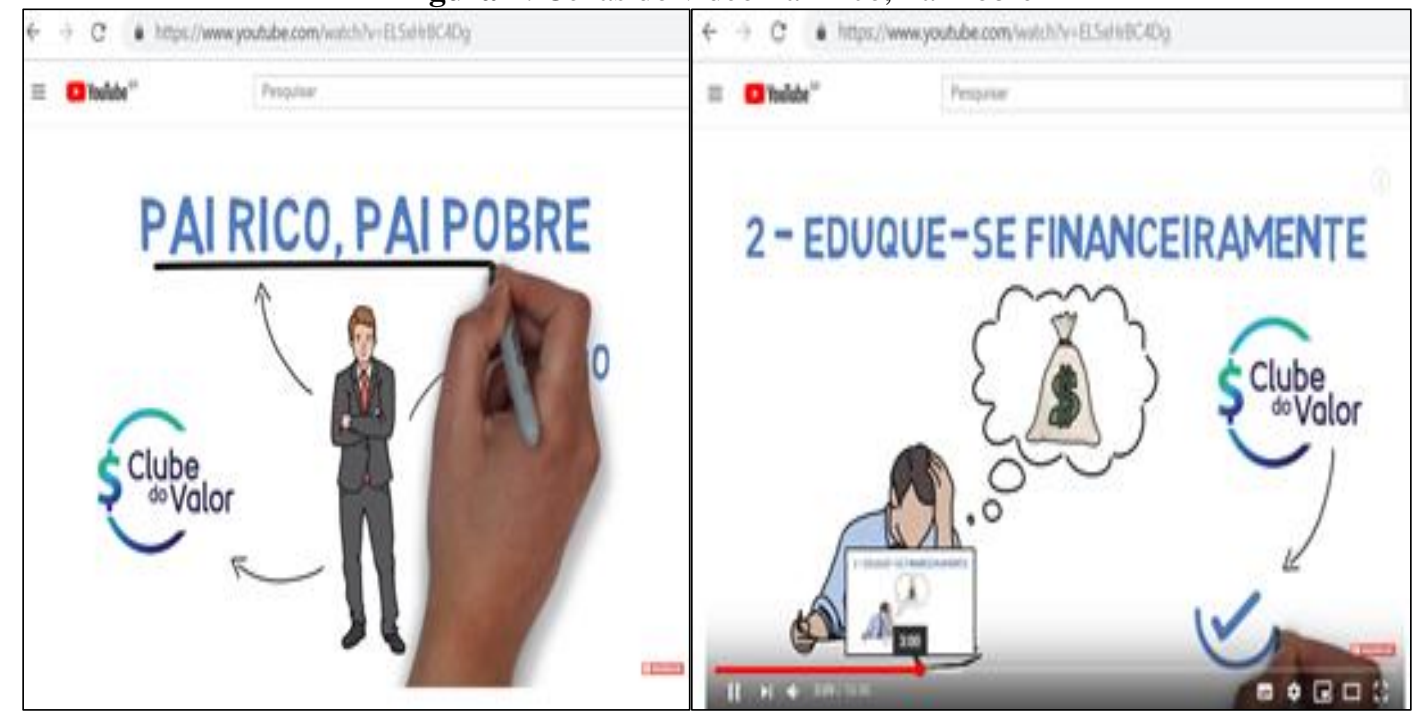

Fonte: https://www.youtube.com/watch?v=EL5xHrBC4Dg

O módulo sugere a leitura de documentos sobre o tema: Base Nacional Comum Curricular e a Estratégia Nacional de Educação Financeira. Esse é um dos momentos que motivam a abordagem da Educação Financeira nas escolas. Esta atividade proporciona contato com a BNCC como um todo, pois no curso, há a indicação do link para consulta do documento na íntegra. Cabe destacar que o podcast disponibilizado no curso faz 


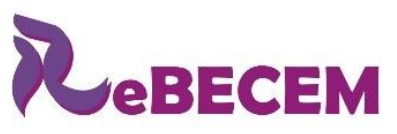

DOI: http://dx.doi.org/10.33238/ReBECEM.2019.v.3.n.2.22611

reflexões sobre como são as atitudes dos brasileiros, através de situações cotidianas e nele é possível perceber como é importante trabalhar a educação financeira com os brasileiros. Buscando ainda colaborar com essa atividade, em "Saiba Mais" encontram-se duas entrevistas explorando Educação Financeira e a BNCC, e são apresentados ideias e materiais que podem ser aplicados nas escolas.

Com esse módulo o cursista terá a oportunidade de conhecer os documentos que norteiam a abordagem da Educação Financeira nas escolas, pois conhecendo os motivos e os objetivos de se explorar a Educação Financeira fica coerente a abordagem e facilita que esses objetivos sejam integralizados.

\subsubsection{Módulo 3 - Resolução de Problemas e Educação Financeira}

No Módulo 3 opta-se por explorar a resolução de problemas para abordar temas relacionados a Educação Financeira. Nesse sentido, em diversas atividades, explorou-se os passos de resolução de problema apresentado por George Polya, que defende que a resolução de problemas proporciona o desenvolvimento de habilidades necessária aos estudantes.

É nesse contexto que a utilização da resolução de problemas pode auxiliar na exploração da Educação Financeira. Criar estratégias, fazer previsões e planos são habilidades indispensáveis para conseguir lidar com as finanças.

\footnotetext{
Ensinar a resolver problemas é educar a vontade. Na resolução de problemas que, para ele, não são muito fáceis, o estudante aprende a perseverar a despeito de insucessos, a apreciar pequenos progressos, a esperar pela ideia essencial e a concentrar todo o seu potencial quando esta aparecer. Se o estudante não tiver, na escola, a oportunidade de se familiarizar com as diversas emoções que surgem na luta pela solução, a sua educação matemática terá falhado no ponto mais vital (POLYA, 1995, p. 131).
}

Assim, durante a apreciação do Módulo 3, além de abordar a Educação financeira aproveitou-se para explorar a resolução de problemas. Uma das atividades desenvolvidas explorava, a partir de um vídeo, situações que ocorrem frequentemente no supermercado e que nos leva a refletir sobre EF. Na Figura 8 é possível visualizar questionamentos para serem realizados em cada etapa de resolução de problemas sugeridas por Polya (1995) apresentados para uma dessas atividades do supermercado. 
DOI: http://dx.doi.org/10.33238/ReBECEM.2019.v.3.n.2.22611

Figura 8: Resolvendo um problema

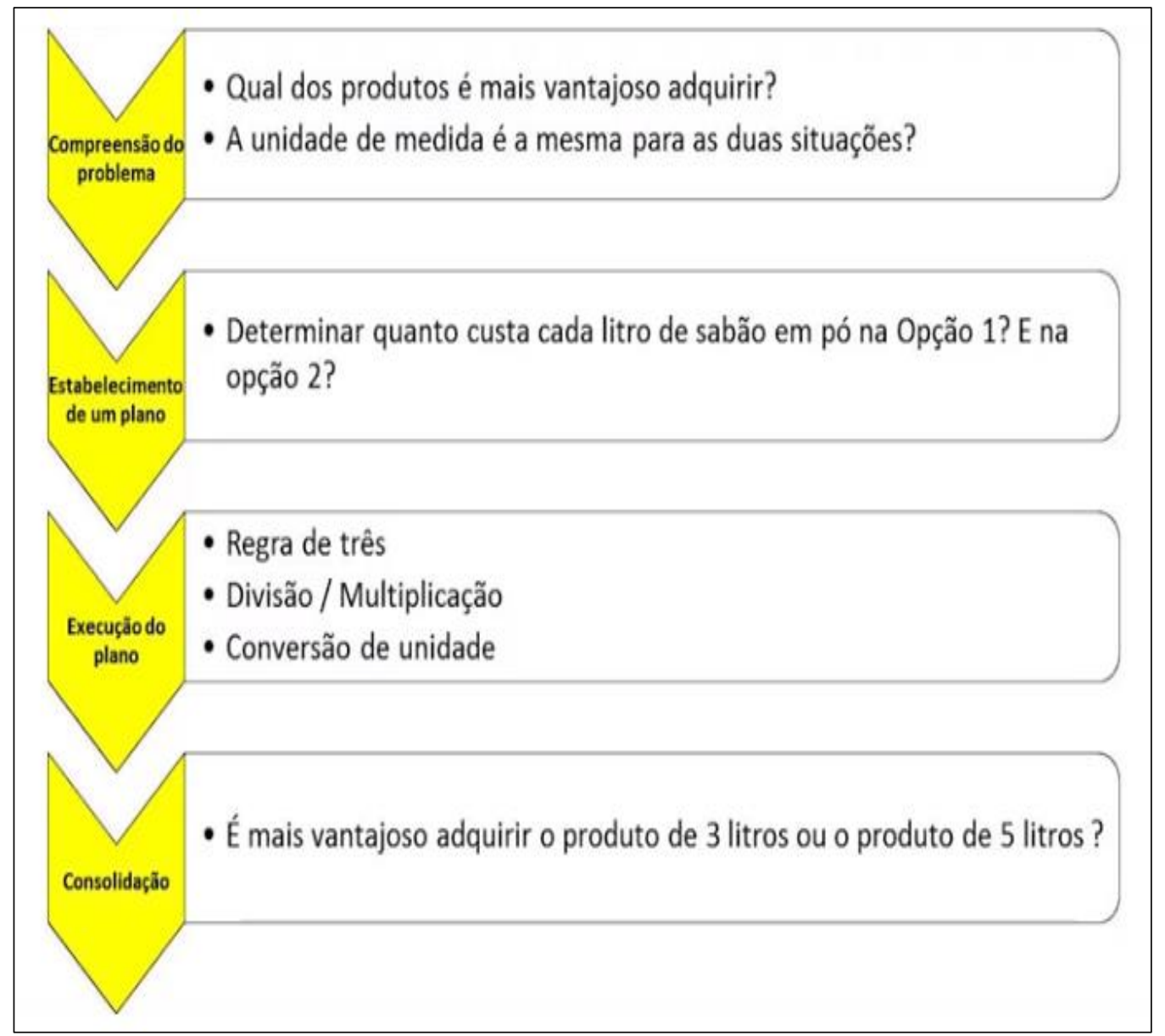

Fonte: Elaborada pelos autores

Dessa forma, ao longo do módulo foram enfatizadas situações cotidianas em que o professor pode explorar conceitos básicos, mas de extrema importância para desenvolver o grau de Educação Financeira. Comparar preços, fazer conversões de unidades para determinar qual produto é mais vantajoso, são alguns dos exemplos explorados neste Módulo.

Por meio das atividades propostas no módulo 3 é possível explorar a interdisciplinaridade com disciplinas da área de línguas e produção de texto, como sugerido na BNCC, essa exploração enfatiza a produção de textos e de charges, além de indicar a leitura de livros. A Figura 9 contempla uma tirinha, onde a atividade do cursista é completá-la. Em contextos que tratam de Educação Financeira os professores da área de línguas podem explorar diferentes tipos de produção textual, sendo essa uma atividade que permite explorar a interdisciplinaridade. 


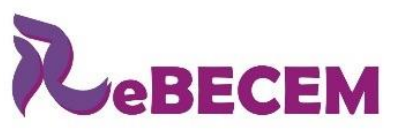

DOI: http://dx.doi.org/10.33238/ReBECEM.2019.v.3.n.2.22611

Figura 9: Calvin e Haroldo e a Aventura da Educação Financeira

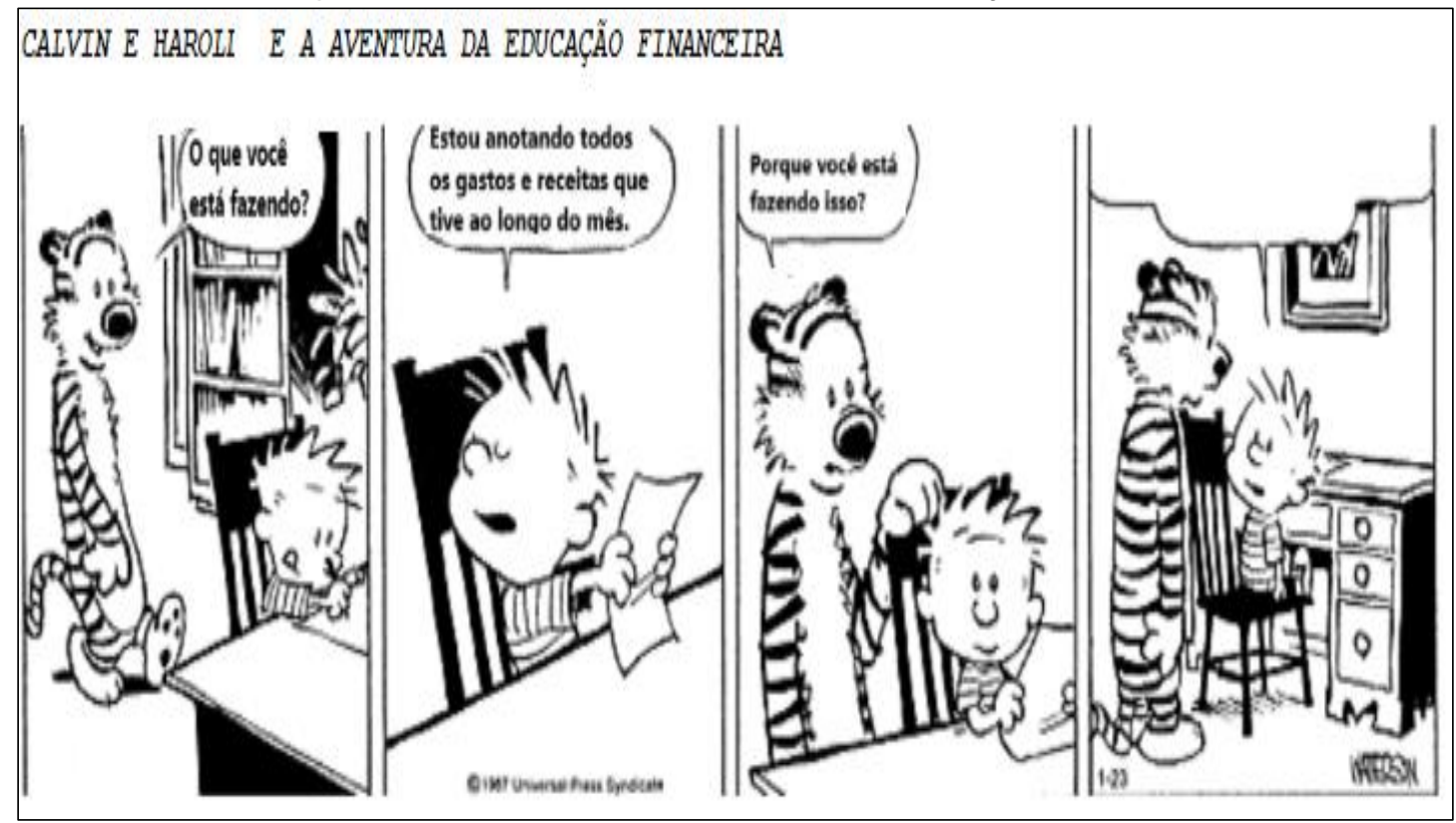

Fonte: Adaptada de: https://novaescola.org.br/conteudo/3621/calvin-e-seus-amigos

Também estão disponíveis neste módulo textos sobre controle de gastos, apresentando aplicativos e planilhas que auxiliam nessa atividade. O Módulo 3 proporciona o acesso a diversas atividades a serem aplicadas em sala de aula, como textos, livros, jogos, aplicativos, vídeo, videoaula, tabelas, charge e planilhas que auxiliam na exploração do tema.

\subsubsection{Módulo 4 - Tópicos de Matemática Financeira}

O Módulo 4 destaca a abordagem da Matemática Financeira a partir de uma série de problemas propostos. Cabe salientar que são disponibilizados materiais como livros, apostilas, vídeos que permitem o embasamento teórico dos tópicos de matemática financeira, bem como sugestões de atividades que podem ser aplicadas em sala de aula. Além das atividades sugeridas, apresentam-se indicados para a leitura artigos que descrevem como explorar o tema.

Nesse módulo explora-se a Matemática Financeira de forma contextualizada, como uma ferramenta que contribui para a tomada de decisões. A ênfase das atividades propostas não está simplesmente em aplicar fórmulas. Trabalhar a matemática financeira em um contexto de Educação Financeira é fazer uma abordagem para além das fórmulas. É utilizá-las para tomada de decisões e melhoria na sua relação com as finanças.

Nesse sentido as atividades propostas no curso "Educação Financeira: Meu aluno precisa disso?" permitem interligar a Educação Financeira, a Matemática Financeira e a 
DOI: http://dx.doi.org/10.33238/ReBECEM.2019.v.3.n.2.22611

metodologia de Resolução de Problemas. Esse tipo de atividade vai ao encontro com o que é enfatizado por Pessoa, Muniz e Kistemann (2018), que defendem que a Educação Financeira quando trabalhada no ambiente escolar seja um chamado à reflexão sobre as atitudes relacionadas à movimentação do dinheiro, além da compreensão das potenciais consequências decorrentes de suas escolhas, e que estimule os alunos a pensarem de maneira mais crítica e analítica.

Nesse contexto, são apresentadas diversas atividades que podem ser aplicadas na sala de aula, sempre apresentando sugestões do que e como explorá-las. As atividades sugeridas nos fóruns proporcionam momentos de interação, e por meio das conversas e das postagens, os participantes do curso tem a oportunidade de estar em contato com diferentes opiniões e pessoas com bagagem diferenciada de experiência.

Pode-se destacar nesse módulo o uso diversificado de ferramentas que contribuem significativamente à aprendizagem e à melhoria na prática pedagógica. Uma das atividades proporciona ao cursista entender o que é uma Webquest ${ }^{6}$ e realizar uma atividade com esse enfoque. A Figura 10, apresenta uma sequência de atividades a serem exploradas pelo cursista com base em vários links selecionados acerca da Educação Financeira. Partindo de uma situação problema, que neste caso é o consumo de cigarro, será possível explorar conceitos de Educação Financeira. Outro ponto a destacar é a possibilidade de exploração de forma interdisciplinar, onde, por exemplo, pode-se abordar os malefícios do consumo de cigarro ao corpo humano.

\footnotetext{
${ }^{6}$ A Webquest caracteriza-se pela pesquisa na internet, em links previamente selecionados que vão ao encontro aos objetivos e temas propostos.
} 
DOI: http://dx.doi.org/10.33238/ReBECEM.2019.v.3.n.2.22611

Figura 10: Atividade usando Webquest

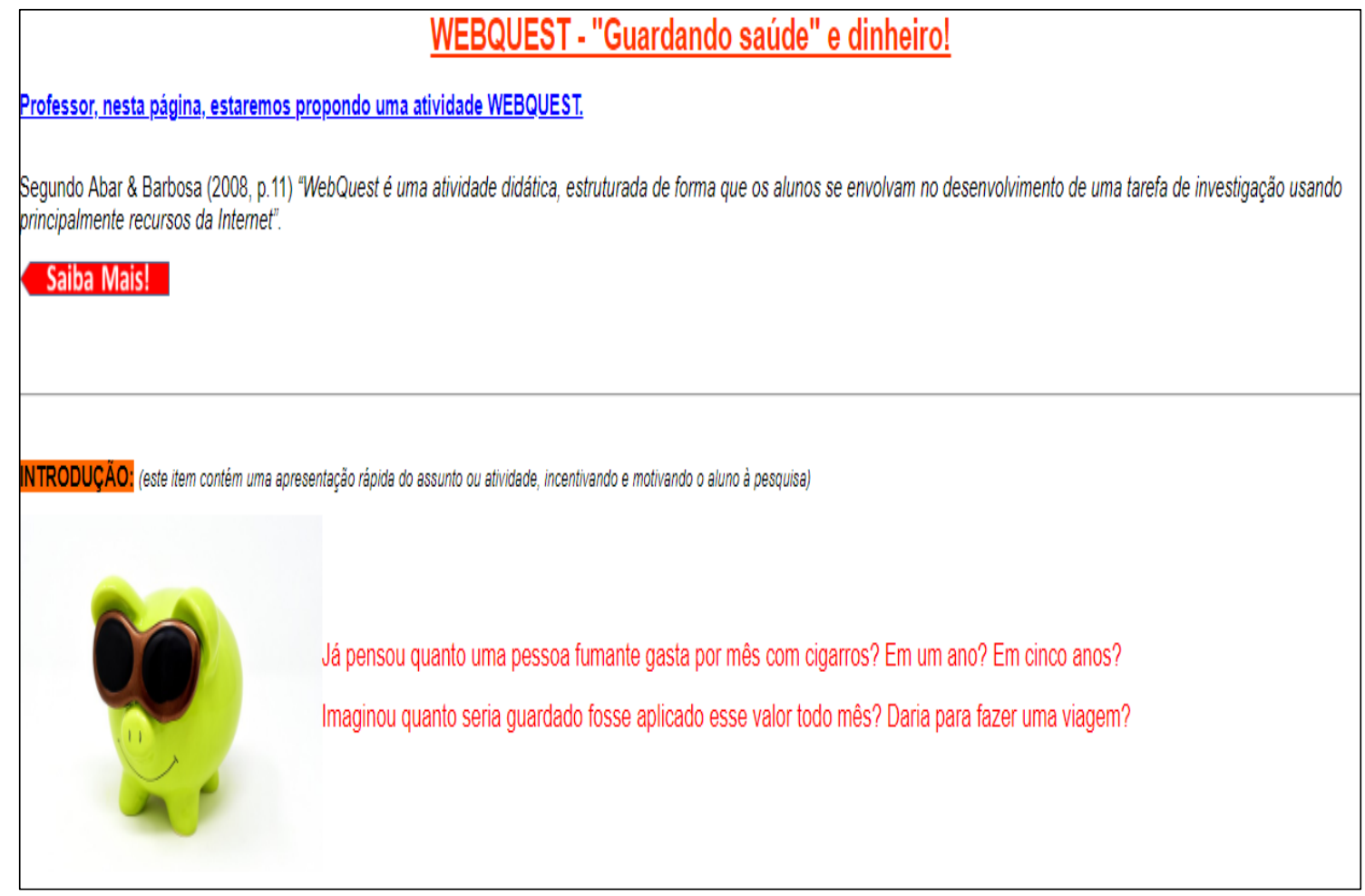

Fonte: Elaborada pelos Autores

\section{Considerações finais}

Abordar o tema Educação Financeira nas escolas é inevitável, devido a atual conjuntura econômica e pela homologação da BNCC em 2018. Porém, sem formação, se torna difícil aos educadores assumir tamanha responsabilidade, visto que, muitos deles não apresentam domínio sobre o tema.

$\mathrm{Na}$ busca de oportunizar os diferentes estilos de aprendizagem, o curso aqui relatado conta com uma diversidade de recursos. Assim, esses recursos ao mesmo tempo em que proporcionam o aprendizado do cursista também podem ser utilizados na prática pedagógica, tornando suas aulas mais atrativas. Outro ponto a destacar diz respeito à interdisciplinaridade, pois favorece a construção do conhecimento de forma articulada. Atividades de formação continuada com este foco são necessárias. Proporcionar aos professores momentos de reflexões e elaboração atividades interdisciplinares a serem aplicada a seus alunos se faz necessário.

Com a participação no curso online: "Educação Financeira: Meu aluno precisa disso", os cursistas, terão um vasto quadro de atividades a serem exploradas em sua prática pedagógica. Os textos, vídeos, e demais ferramentas abordadas no curso podem ser aplicadas e ou adaptadas para estudantes da educação básica. No decorrer do curso 


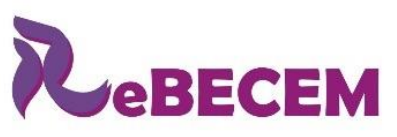

DOI: http://dx.doi.org/10.33238/ReBECEM.2019.v.3.n.2.22611

várias atividades abordam a teoria de Resolução de Problemas como metodologia de ensino, favorecendo o estudo de situações problemas, de situações desafiadoras. Sendo esse um diferencial no modo de ensinar poderá emergir no educador uma provocação aos métodos tradicionais de ensino. Dessa forma, a ênfase dada na BNCC com relação à realização de atividades interdisciplinaridade será contemplada. Por outro lado, novos cursos de formação continuada podem abordar a Educação Financeira por áreas específicas, onde cada educador refletirá sobre sua prática pedagógica pautado no tema proposto.

O Moodle se mostrou adequado ao desenho instrucional idealizado, com curva de aprendizagem suave sobre os elementos necessários à criação do curso. Um ponto negativo para a criação do curso com o ambiente Moodle está relacionado ao versionamento da plataforma, com algumas limitações na interface, necessitando de plugins adicionais que precisam ser integrados à plataforma para obter um design mais adaptativo ao usuário, não sendo possível sua implementação para esse momento.

É improdutivo afirmar apenas que é dever das escolas melhorar o grau de Educação Financeira de seus estudantes, sem preparar e oportunizar formação aos professores. A formação continuada é, em geral, um processo incessante que visa enriquecer o conhecimento dos professores, sendo uma ação necessária na busca constante por melhorias na prática pedagógica. Nesse curso, que ainda não está disponível, mas com previsão de oferta de turma no segundo semestre de 2019, dá-se o ponta pé inicial à abordagem do tema.

Após a oferta e avaliação do curso pelos participantes de sua experiência ao cursálo, será possível averiguar a necessidade de mudanças e incrementos. Ainda, na busca de dar prosseguimento a oferta de cursos de formação continuada online, outros cursos com ênfase no tema Educação Financeira podem emergir, cuja abordagem dada pode ser por atividades categorizada por série escolar e com foco na interdisciplinaridade, envolvem diversos componentes curriculares.

\section{Referências}

BCB. Caderno de Educação Financeira - Gestão de Finanças Pessoais. Banco Central do Brasil. Brasília, DF, 2013. p. 1-72.

BORBA, M. C.; MALHEIROS, A. P. S.; AMARAL, R. B. Educação a distância. 3. ed. Belo Horizonte: Autêntica, 2011. 


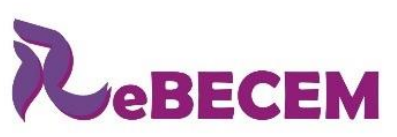

Revista Brasileira de Educação em

Ciências e Educação Matemática

ISSN 2594-9179

DOI: http://dx.doi.org/10.33238/ReBECEM.2019.v.3.n.2.22611

BRASIL. Secretaria de Educação Fundamental. Parâmetros Curriculares Nacionais: Matemática. Brasília, DF, 1998.

BRASIL. Casa Civil. Decreto no 7.397, de 22 de dezembro de 2010. Institui a Estratégia Nacional de Educação Financeira - ENEF, dispõe sobre a sua gestão e dá outras providências. Brasília, DF, 2010.

BRASIL. Casa Civil. Decreto no 9.057, de 25 de maio de 2017. Estabelece as diretrizes e bases da educação nacional. Brasília, DF, 2017. Disponível

em: http://www.planalto.gov.br/ccivil_03/_Ato2015-2018/2017/Decreto/D9057.htm\#art24.

Acesso em: 10 jun. 2019.

BRASIL. Ministério da Educação. Base Nacional Comum Curricular (BNCC). Educação é a Base. Brasília, DF, 2018. Disponível em: http://basenacionalcomum.mec.gov.br/a-base. Acesso em: 20 maio. 2019.

CUNHA, C. L.; LAUDARES, J. B. Resolução de Problemas na Matemática Financeira para Tratamento de Questões da Educação Financeira no Ensino Médio. Bolema, Rio Claro, v. 31, n. 58, p. 659-678, ago. 2017.

DANTE, L. R. Didática da resolução de problemas de matemática: $1^{\mathrm{a}}$ a $5^{\mathrm{a}}$ séries: para estudantes do curso de Magistério e professores do 1. grau. 10. ed. São Paulo: Ática, 1998.

DANTE, L. R. Matemática, volume único: manual do professor. 1. ed. São Paulo: Ática, 2005.

PEREIRA, A. G.; LARANJO, J. C; FIDALGO, F. S. R. Formação continuada de professores e EaD: superação de limites e limites da superação. In: SIMPÓSIO INTERNACIONAL DE EDUCAÇÃO À DISTÂNCIA, 2012, São Paulo. Anais... São Paulo: Universidade Federal de São Carlos, 2012. p. 1-11. Disponível em: < http://sistemas3.

sead.ufscar.br/ojs/Trabalhos/72-852-1-ED.pdf>. Acesso em: 30 jun. 2019.

FILATRO, A. Design instrucional na prática. 1. ed. São Paulo: Pearson, 2008.

FIORENTINI, D. A pesquisa e as práticas de formação de professores de matemática em face das políticas públicas no Brasil. Bolema, Rio Claro, v. 21, n. 29, p. 43-70, 2008.

GHEDIN, E. Professor reflexivo: da alienação da técnica à autonomia da crítica. In: PIMENTA, S. G.; GHEDIN, E. (org.). Professor Reflexivo no Brasil: gênese e crítica de um conceito. 7. ed. São Paulo: Cortez, p. 148-173, 2012.

KIYOSAKI, R. T. Pai Rico, Pai Pobre. 1. ed. Rio de Janeiro: Alta Books, 2017.

PESSOA, C. A. S.; MUNIZ I. Jr.; KISTEMANN, M. A. Jr. Cenários sobre educação financeira escolar: entrelaçamentos entre a pesquisa, o currículo e a sala de aula de Matemática. Revista de Educação Matemática e Tecnológica Ibero-americana, Pernambuco, v. 9, n. 1, p. 1-28, 2018.

POLYA, G. A arte de resolver problemas: um novo aspecto do método matemático. 2. ed. Rio de Janeiro: Interciência, 1995.

SANTOS, L. R. Educação Financeira na Agenda da Responsabilidade Social Empresarial.

Boletim Responsabilidade Social e Ambiental do Sistema Financeiro, Brasília, ano 4, n. 39, p. 1-2, fev. Disponível em: https://www.bcb.gov.br/pre/boletimrsa/BOLRSA200902.pdf. Acesso em: maio. 2019. 
SAVOIA, J. R. F.; SAITO, A. T.; SANTANA, F. de A. Paradigmas da educação financeira no Brasil. Rev. Adm. Pública, Rio de Janeiro, v. 41, n. 6, p. 1121-1141, nov./dez. 2007.

WENGZYNSKI, D.; TOZETTO, S. S. A formação continuada face as suas contribuições para a docência. In: SEMINÁRIO DE PESQUISA DO PPE, 2012, Maringá. Anais... Maringá: UEM, 2012. p. 1-16. Disponível em:

http://www.ppe.uem.br/publicacoes/seminario_ppe_2012/trabalhos/po/po_008.pdf. Acesso em: maio. 2019.

Recebido em: 14 de junho de 2019.

Aceito em: 20 de julho de 2019. 